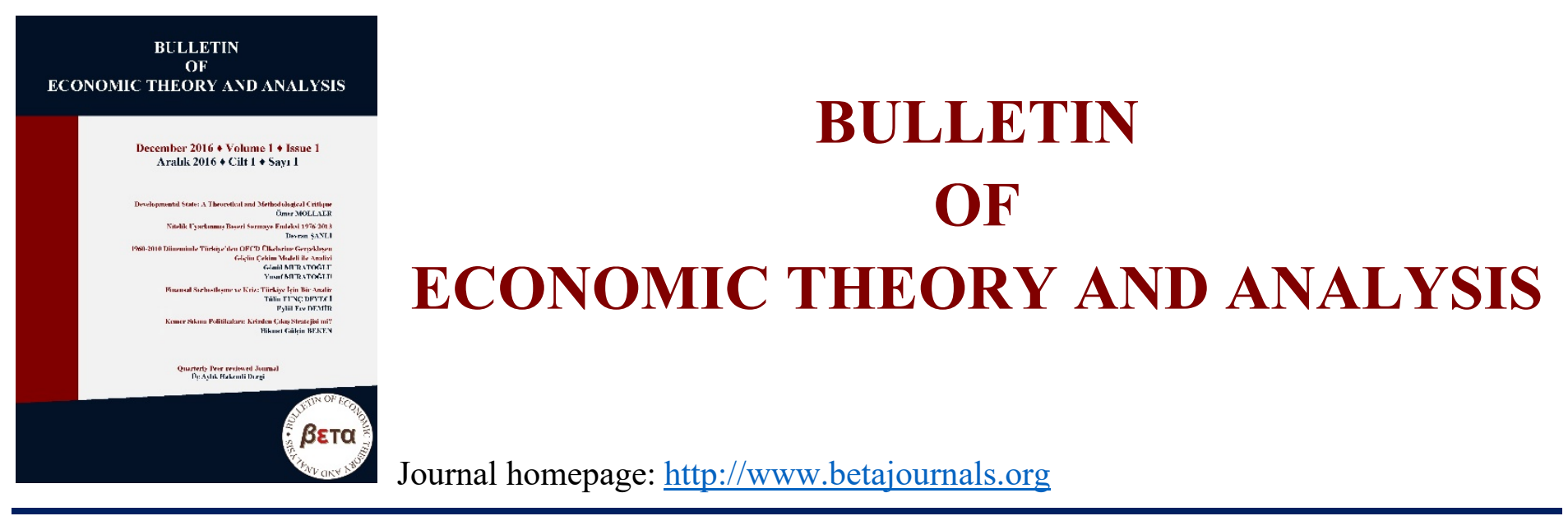

\title{
Do Agricultural Raw Materials Imports Cause Agricultural Growth? Empirical Analysis from North Africa
}

\section{Sayef BAKARI $\odot$ https://orcid.org/0000-0002-5395-4348}

To cite this article: Bakari, S. (2019). Do Agricultural Raw Materials Imports Cause Agricultural Growth? Empirical Analysis from North Africa. Bulletin of Economic Theory and Analysis, 4(2), 6577.

Received: 02 Apr 2019

Accepted: 19 Aug 2019

Published online: 01 Dec 2019

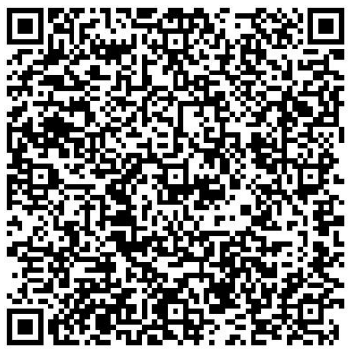




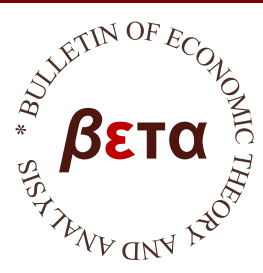

\title{
Bulletin of Economic Theory and Analysis
}

Volume IV, Issue 2, pp. 65-77, 2019

http://www.betajournals.org

Original Article / Araştırma Makalesi

Received / Alınma: 02.04.2019 Accepted / Kabul: 19.08.2019

\section{Do Agricultural Raw Materials Imports Cause Agricultural Growth? Empirical Analysis from North Africa}

\author{
Sayef BAKARI ${ }^{\mathrm{a}}$ \\ ${ }^{a}$ Ph.D., Department of Economics Science, LIEI, Faculty of Economic Sciences and Management of Tunis \\ (FSEGT), University Of Tunis El Manar, TUNISIA@https://orcid.org/0000-0002-5395-4348
}

\begin{abstract}
The aim of this paper is to study empirically the impact of agricultural raw materials imports on agricultural growth since it is never done before. We have made this study in the context of three Countries from North Africa (Tunisia, Morocco and Egypt) for the period 1965 - 2016. By using cointegration analysis and vector error correction model, empirical analysis proves that agricultural raw materials imports produce a positive effect on agricultural growth in the long run for the three Countries and cause agricultural growth in the short run in the case of Tunisia and Egypt. It is seen that agricultural raw materials imports is a source of economic growth in the agricultural sector. For this reason, countries of North Africa should adopt to integrate foreign technology imports and not technological innovation to stimulate agricultural sector.

Anahtar Kelimeler Agricultural Raw Materials Imports, Agricultural Growth, VECM, North Africa.

\section{JEL Kodu}

F11, F13, F14, F15, L66, O47, O55, Q16, Q17
\end{abstract}

CONTACT Sayef BAKARI, $\square$ bakari.sayef@yahoo.fr छ'Department of Economics Science, LIEI, Faculty of Economic Sciences and Management of Tunis (FSEGT), University Of Tunis El Manar, TUNISIA 


\section{Introduction}

Generally, for developing countries, imports of capital goods and intermediate goods are essential inputs because these types of countries cannot produce these goods and because they are incorporated in the technology they need. And if there is not enough foreign exchange to finance imports of capital goods and intermediate goods, the economy neither functions properly nor will economic growth be strong 1 . Amsden (1989) claimed that foreign technology imports are an important factor in explaining the rapid economic growth. He suggested that a growth model suitable should integrate not technological innovation but foreign technology imports. Grossman and helpman (1991), Barro and sala-I-Martin (1997), Benhabib and sepiegel (2002) and Griffith et al (2004) declare that the spreading of new technologies from developing economies to developing ones is considered as an essential driver of productivity growth for developing countries.Benhabib and Sepiegel (2002), Griffith et al (2004), Cameron et al (2005) propose that countries which are overdue behind the technological frontier will experience faster productivity growth than the leading country and thus benefit from technological catch-up.Bel Haj Hassine (2008) explored the role of human capital and trade openness in the process of technological diffusion and productivity growth in the Mediterranean agricultural sector. She found that human capital and trade openness facilitates technology diffusion and stimulates agricultural growth.Margot Anderson (1989) argues that technology transfer helps to increase agricultural productivity, reduces production costs and lowers consumer prices. Indicating that benefits depend on the way technology is transferred, the speed of transfer and the degree of influence of government policy on technology transfers.DeJanvry and Sadoulet (2001) have shown that technology in the agricultural sector can contribute to reducing poverty through direct effects (gain for adopters) and indirect effects (lower food prices, job creation, effects related to agricultural investment and agricultural growth...,).Such an empirical exercise has never been done before in the context of North Africa and in the context of the impactof agricultural raw materials imports on Agricultural growth. In this research, we try to bridge these gaps by looking into the impact of agricultural raw materials imports on agricultural growth for the period 1965 to 2016. The rest of the paper is fixed as follows. Section 2 establishes on a survey of literature. Section 3 explains the data characterization and methodological structure.

\footnotetext{
${ }^{1}$ see: Chenery and Bruno (1962), Mckinnon (1964) and Taylor (1991)
} 
Empirical results and analysis are engaged into account in next coming Section 4. Section 5 ends the study along with recommendations.

\section{Literature Survey}

The following table presents a set of empirical studies that are collected during our exploration of this research theme to inspire the realization of our empirical analysis.

Table 1

Studies Related to the Nexus Between Imports / Economic Growth and Between Imports Diversification and Economic Growth

\begin{tabular}{|c|c|c|c|c|c|}
\hline No & Authors & Countries & Periods & $\begin{array}{l}\text { Econometric } \\
\text { Techniques }\end{array}$ & $\begin{array}{l}\text { Keys } \\
\text { Findings }\end{array}$ \\
\hline \multicolumn{6}{|c|}{ Imports and Economic Growth } \\
\hline 1 & Hye (2012) & China & $1978-2009$ & ARDL & $\mathrm{M}<=>\mathrm{Y}:$ \\
\hline & & & & Granger Causality Tests & LR \\
\hline 2 & Alavinasab (2013) & Iran & $1961-2010$ & OLS & $M=>Y:(-)$ \\
\hline 3 & Ahmed and al (2014) & Pakistan & $1983-2013$ & $\begin{array}{l}\text { Cointegration Analysis } \\
\text { Granger Causality Tests }\end{array}$ & $M=>Y$ \\
\hline 4 & $\begin{array}{l}\text { Albiman and Suleiman } \\
(2016)\end{array}$ & Malaysia & $1967-2010$ & $\begin{array}{l}\text { Cointegration Analysis } \\
\text { VAR } \\
\text { Granger Causality Tests }\end{array}$ & $\mathrm{M} \# \mathrm{Y}$ \\
\hline 5 & $\begin{array}{l}\text { Riyath and Jahfer } \\
\text { (2016) }\end{array}$ & Sri Lanka & $1962-2015$ & $\begin{array}{l}\text { Cointegration Analysis } \\
\text { VECM }\end{array}$ & $\begin{array}{l}M \# Y: S R \\
M=>Y: L R\end{array}$ \\
\hline 6 & Bakari (2017) & Tunisia & $1965-2016$ & $\begin{array}{l}\text { Cointegration Analysis } \\
\text { VECM }\end{array}$ & $\begin{array}{l}M=>Y: L R \\
M \# Y: S R\end{array}$ \\
\hline 7 & $\begin{array}{l}\text { Bakari and Mabrouki } \\
(2017)\end{array}$ & Panama & $1980-2015$ & $\begin{array}{l}\text { Cointegration Analysis } \\
\text { VAR } \\
\text { Granger Causality Tests }\end{array}$ & $\mathrm{M}=>\mathrm{Y}$ \\
\hline 8 & Bakari and al (2018) & Nigeria & $1981-2015$ & $\begin{array}{l}\text { Cointegration Analysis } \\
\text { VECM }\end{array}$ & $\begin{array}{l}M \# Y: L R \\
M<=>Y: \\
S R\end{array}$ \\
\hline 9 & $\begin{array}{l}\text { Ofeh and } \\
\text { Muandzevara (2017) }\end{array}$ & Cameroon & $1980-2013$ & $\begin{array}{l}\text { Correlation Analysis } \\
\text { OLS }\end{array}$ & $\begin{array}{l}M=>Y:(-) \\
M=>Y: L R\end{array}$ \\
\hline \multicolumn{6}{|c|}{ Imports diversification and economic growth } \\
\hline 10 & Zhang and Zou (1995) & $\begin{array}{l}50 \text { Developing } \\
\text { Countries }\end{array}$ & $1965-1988$ & $\begin{array}{l}\text { Pooled OLS } \\
\text { Fixed Effect Model } \\
\text { Random Effect Model }\end{array}$ & $\mathrm{FTM}=>\mathrm{Y}$ \\
\hline 11 & Ghosh (2009) & India & $1970-2006$ & $\begin{array}{l}\text { Cointegration Analysis } \\
\text { ARDL }\end{array}$ & OM \# Y : LR \\
\hline 12 & $\begin{array}{l}\text { Jayaraman and Lau } \\
\text { (2011) }\end{array}$ & $\begin{array}{l}\text { Fiji, Samoa, } \\
\text { Solomon Islands, } \\
\text { Tonga and Vanuatu }\end{array}$ & $1982-2007$ & $\begin{array}{l}\text { PFMOLS } \\
\text { Panel Cointegration } \\
\text { Analysis } \\
\text { Panel Granger } \\
\text { Causality Tests }\end{array}$ & $\begin{array}{l}\mathrm{OM}=>\mathrm{Y}: \\
\mathrm{LR}(-)\end{array}$ \\
\hline 13 & & & $1980-2007$ & PFMOLS & $\mathrm{OM}<=\mathrm{Y}$ \\
\hline
\end{tabular}




\begin{tabular}{|c|c|c|c|c|c|}
\hline & $\begin{array}{l}\text { Yazdani and } \\
\text { Faaltofighi (2012) }\end{array}$ & $\begin{array}{l}\text { Turkey, South Korea } \\
\text { Malaysia, India and } \\
\text { Pakistan }\end{array}$ & & PVECM & \\
\hline 14 & Acheampong (2013) & Ghana & $1967-2011$ & Cointegration Analysis & $\begin{array}{l}\mathrm{OM}=>\mathrm{Y} \\
\mathrm{LR}(-)\end{array}$ \\
\hline & & & & ARDL & $\begin{array}{l}\mathrm{OM}=>\mathrm{Y} \\
\mathrm{SR}(-)\end{array}$ \\
\hline 15 & $\begin{array}{l}\text { Bakari and Mabrouki } \\
\text { (2018) }\end{array}$ & North Africa & $1982-2016$ & $\begin{array}{l}\text { Correlation Analysis } \\
\text { Fixed Effect Model } \\
\text { Random Effect Model } \\
\text { Hausman Test }\end{array}$ & $\mathrm{AM}=>\mathrm{Y}$ \\
\hline
\end{tabular}

Note. Y means Economic Growth, M means Imports, AM means Agricultural Imports, OM means Oil Imports, FTM means Foreign Technology Imports, LR means Long Run, SR means Short Run, (-) means Negative Effect

\section{Data, Methodology and Model Specification}

\subsection{Data}

To perambulate the impact of Agricultural raw materials imports on Agricultural GDP in North Africa, we will utilize a time series database that will spread the period 1965 - 2016 and taken from annual statistical reports of the World Bank. The short illustration of variables is specific as below in Table 2 .

Table 2

\section{Description of Variables}

\begin{tabular}{|c|c|c|c|}
\hline No & Variables & Description/Definition & Source \\
\hline 1 & $\mathrm{AY}$ & $\begin{array}{l}\text { Agricultural Gross Domestic Product (constant US \$): agriculture } \\
\text { corresponds to ISIC divisions } 1-5 \text { and includes forestry, hunting, and } \\
\text { fishing, as well as cultivation of crops and livestock production. } \\
\text { Value added is the net output of a sector after adding up all outputs } \\
\text { and subtracting intermediate inputs. It is calculated without making } \\
\text { deductions for depreciation of fabricated assets or depletion and } \\
\text { degradation of natural resources. The origin of value added is } \\
\text { determined by the International Standard Industrial Classification } \\
\text { (ISIC), revision } 3 \text { or } 4 \text {. }\end{array}$ & The World Bank \\
\hline 2 & $\mathrm{AX}$ & $\begin{array}{l}\text { Agricultural Export (Constant US \$): comprises the commodities in } \\
\text { SITC sections } 0 \text { (food and live animals), } 1 \text { (beverages and tobacco), } \\
\text { and } 4 \text { (animal and vegetable oils and fats) and SITC division } 22 \text { (oil } \\
\text { seeds, oil nuts, and oil kernels), (constant US \$) }\end{array}$ & The World Bank \\
\hline 3 & AMM & $\begin{array}{l}\text { Agricultural raw materials imports (constant US \$): comprise SITC } \\
\text { section } 2 \text { (crude materials except fuels) excluding divisions } 22,27 \\
\text { (crude fertilizers and minerals excluding coal, petroleum, and } \\
\text { precious stones), and } 28 \text { (metalliferous ores and scrap). }\end{array}$ & The World Bank \\
\hline
\end{tabular}




\subsection{Methodology}

Methodologically, an estimate based on the development of VAR models introduced by Sims (1980) will be used to identify the nature of the temporal link between the main macroeconomic aggregates. The first step includes determining the order of integration of each variable (If the variables are all stationary we can apply the model of Sims, and if not, we cannot apply it). The second step is to determine the number of optimal lags included in our model to know the time needed (per year) for the independent variables to cause an effect (whether positive / negative) on the dependent variables. The third step is to check the existence or the absence of a cointegration relation between the variables (if there is a cointegration relation we will apply the VECM Model, if there is not a cointegration relation we will apply the VAR Model).

\subsection{Model Specification}

To inspect empirically the impact of agricultural raw materials imports on agricultural growthis expressed as ${ }^{2}$ :

$$
A Y=F(A X, A M M)
$$

Where AY, AX and AMM depict respectively: gross domestic product in agricultural sector (Constant US \$), agricultural export (Constant US \$) and agricultural raw materials imports (Constant US \$).

The Function can also be represented in log-linear econometric format thus:

$$
\log (A Y)=\beta_{0}+\beta_{1} \log (A X)_{t}+\beta_{2} \log (A M M)_{t}+\varepsilon_{t}
$$

Where:

- $\quad \boldsymbol{\beta}_{\mathbf{0}}$ is the constant term

\footnotetext{
2 This modality of production function is very dynamic and very transparent to substantiate the nexus between trade and economic growth, largely in the developing countries and predominately, in the countries of Africa as the case of Egypt, Morocco and Tunisia, since these countries take holding of various natural resources and rare goods such as oil, gas, phosphate, gold, copper, iron, phosphorus for export, and generally require high-level imports to extract these resources (such as; Imports of manufactured goods, Imports of ICT goods, Imports of ores and metals). In addition, the share of investment and labor force are not of considerable effectiveness simply because of the emergence of percentages of unemployment, poverty and Corruption in these countries \{See Central Bank of Tunisia (1965 - 2016), World Bank indicators and Transparency International $\}$. In addition, there are independent researchers in this field who have applied only the two variables export and import in the function of production to extract their relations with economic growth, such as Hussain (2014); Turan and Karamanaj (2014); Mohsen (2015); Yüksel and Zengin (2016), Bakari (2017), Bakari and Mabrouki (2017), Bakari (2018).
} 
- $\quad \boldsymbol{\beta}_{\mathbf{1}}$ is the coefficient of variable 'agricultural export'

- $\quad \boldsymbol{\beta}_{\mathbf{2}}$ is the coefficient of variable 'agricultural raw materials imports)

- $\quad \mathbf{t}$ is the time rend (by year)

- $\quad \boldsymbol{\varepsilon}$ is the random error term assumed to be normally, identically and independently distributed

Equation (2) can be written in Error Correction Model form as:

$$
\Delta \mathrm{AY}_{(\mathrm{t})}=\sum_{(\mathrm{i}-1)}^{\mathrm{k}} \beta_{0} \Delta \mathrm{AY}_{\mathrm{t}-\mathrm{i}}+\sum_{(\mathrm{i}-1)}^{\mathrm{k}} \beta_{(1)} \Delta \mathrm{AX}_{(\mathrm{t}-\mathrm{i})}+\sum_{(\mathrm{i}-1)}^{\mathrm{k}} \beta_{(2)} \Delta \mathrm{AMM}_{(\mathrm{t}-\mathrm{i})}+\mathrm{Z}_{(1)} \mathrm{ECT}_{(\mathrm{t}-1)}+\varepsilon_{(\mathrm{t})}
$$

Where $\Delta$ is the difference operator; $k$ is the number of lags, $\beta_{0}, \beta_{1}$ and $\beta_{2}$ are the short run coefficients to be estimate; $E C 1_{t-1}$ is the error correction term derived from the long-run co integration relationship; $Z_{1}$ is the error correction coefficients of $E C 1_{t-1}$ and $\varepsilon_{1 t}$ is the error terms in equation.

\section{Empirical Analysis}

As usual, the first step in performing estimation based on VAR model modeling is stationary analysis. There are several tests that determine the order of integration of each variable such as ADF, PP and KPSS. In our case, we will use the most adopted test which is the ADF test ${ }^{3}$.

Table 3

\section{Augmented Dickey Fuller Test}

\begin{tabular}{|c|c|c|c|c|c|c|}
\hline \multirow[t]{2}{*}{ Variables } & \multicolumn{2}{|c|}{ Egypt } & \multicolumn{2}{|c|}{ Morocco } & \multicolumn{2}{|c|}{ Tunisia } \\
\hline & $\mathbf{C}$ & $\overline{C T}$ & $\mathrm{C}$ & $\overline{C T}$ & $\mathbf{C}$ & $\overline{C T}$ \\
\hline \multirow[t]{2}{*}{ AY } & (1.463859) & $(1.752586)$ & $(0.791663)$ & $(3.113750)$ & (1.102977) & $(3.832720)^{* *}$ \\
\hline & {$[8.315827]^{* * *}$} & {$[8.545897]^{* * *}$} & {$[14.51686]^{* * *}$} & {$[14.35747]^{* * *}$} & {$[5.082067]^{* * * *}$} & {$[5.527687]^{* * *}$} \\
\hline \multirow[t]{2}{*}{$\mathrm{AX}$} & $(0.351095)$ & (1.479282) & $(0.146829)$ & $(2.781120)$ & $(0.037970)$ & (2.014369) \\
\hline & {$[6.767956]^{* * *}$} & {$[6.919399]^{* * *}$} & {$[7.428073]^{* * *}$} & {$[7.418593]^{* * *}$} & {$[9.768890]^{* * *}$} & {$[9.907908]^{* * *}$} \\
\hline \multirow[t]{2}{*}{ AMM } & $(2.170230)$ & $(4.768593)^{* * *}$ & $(2.950329)$ & $(2.773951)$ & $(1.122097)$ & $(3.832289)^{* *}$ \\
\hline & {$[7.881689]^{* * *}$} & {$[7.799699]^{* * *}$} & {$[7.738695]^{* * *}$} & {$[8.053752]^{* * *}$} & {$[8.403844]^{* * *}$} & {$[8.357375]^{* * *}$} \\
\hline
\end{tabular}

${ }^{3}$ Augmented Dickey Fuller test, See: Dickey and Fuller $(1979,1981)$ 
The results of the ADF test are described in Table 3. All the variables are stationary and especially they are stationary in first difference. The second step in our empirical analysis is the cointegration analysis. In this case, we will apply the Johansen test which is most appropriate in checking the existence or absence of a cointegration relationship between the variables. It should be noted that the results of the Lag Order Selection VAR indicate that the number of optimal delays is equal to 4 in the case of Egypt and 2 in the case of Tunisia and Morocco.

Table 4

Johansen Test

\begin{tabular}{|c|c|c|c|c|}
\hline \multicolumn{5}{|c|}{ Unrestricted Cointegration Rank Test (Trace) } \\
\hline \multicolumn{5}{|l|}{ Egypt } \\
\hline Hypothesized No. of CE(s) & Eigen Value & Trace Statistic & 0.05 Critical Value & Prob. ** \\
\hline None * & 0.383183 & 47.42711 & 29.79707 & 0.0002 \\
\hline At most $1 *$ & 0.319348 & 24.71754 & 15.49471 & 0.0016 \\
\hline At most $2 *$ & 0.131686 & 6.636465 & 3.841466 & 0.0100 \\
\hline \multicolumn{5}{|l|}{ Morocco } \\
\hline Hypothesized No. of CE(s) & Eigen Value & Trace Statistic & 0.05 Critical Value & Prob. ** \\
\hline None * & 0.453713 & 57.56817 & 29.79707 & 0.0000 \\
\hline At most $1 *$ & 0.317091 & 28.54688 & 15.49471 & 0.0003 \\
\hline At most $2 *$ & 0.192113 & 10.23997 & 3.841466 & 0.0014 \\
\hline \multicolumn{5}{|l|}{ Tunisia } \\
\hline Hypothesized No. of CE(s) & Eigen Value & Trace Statistic & 0.05 Critical Value & Prob. ** \\
\hline None $*$ & 0.460966 & 63.14962 & 29.79707 & 0.0000 \\
\hline At most $1 *$ & 0.301816 & 33.48673 & 15.49471 & 0.0000 \\
\hline At most $2 *$ & 0.287067 & 16.24162 & 3.841466 & 0.0001 \\
\hline
\end{tabular}

Trace test indicates 3 co-integrating equations at the 0.05 level

* denotes rejection of the hypothesis at the 0.05 level

**MacKinnon-Haug-Michelis (1999) p-values

Johansen's test ${ }^{4}$ results indicate the existence of 3 cointegration relationships between the 3 variables in the 3 countries. Since all the variables are co integrated in the 3 countries, the vector error correction model will be retained. Among the virtues of applying an estimation based on the VECM model is the determination of the relationship between all variables in the long-term and the short-term.

The VECM estimate for each country gives us three long-run equilibrium equations, which are presented as follows:

${ }^{4}$ Johansen test, See: Johansen (1988, 1991); Johansen and Juselius (1990) 
Egypt:

$$
\log (A Y)=0.0276+0.0223 \log (A X)+0.0433 \log (A M M)
$$

Morocco:

$$
\log (A Y)=0.0016+0.7642 \log (A X)+0.4078 \log (A M M)
$$

Tunisia:

$$
\log (A Y)=0.0074+0.2827 \log (A X)+0.8669 \log (A M M)
$$

Equations (4), (5) and (6) indicate that agricultural machinery imports and agricultural exports have a positive effect on long-term agricultural GDP in the three countries. It manifests that:

$\checkmark$ In Egypt, agricultural raw material imports and agricultural exports have a positive effect on economic growth, a $1 \%$ increase in $\log (\mathrm{AMM})$ and in $\log (\mathrm{AX})$ leads respectively to an increase of $0.0433 \%$ and $0.0223 \%$ of $\log (\mathrm{Y})$.

$\checkmark$ In Morocco, agricultural raw material imports and agricultural exports have a positive effect on economic growth, a $1 \%$ increase in $\log (\mathrm{AMM})$ and in $\log (\mathrm{AX})$ leads respectively to an increase of $0.4078 \%$ and $0.7642 \%$ of $\log (\mathrm{Y})$.

$\checkmark$ In Tunisia, agricultural raw material imports and agricultural exports have a positive effect on economic growth, a $1 \%$ increase in $\log (\mathrm{AMM})$ and in $\log (\mathrm{AX})$ leads respectively to an increase of $0.8669 \%$ and $0.2827 \%$ of $\log (\mathrm{Y})$.

To verify the credibility of its results we must test the significance of equations of longterm equilibrium by using the Least Squares of Gauss Newton.If the coefficient of the error correction term (Lagged ECT) is negative and possesses a significant probability. This means that all variables in the long-term relationship are significant in explaining the dependent variables. 
Table 5

VECM Estimation

\begin{tabular}{|c|c|c|c|}
\hline \multirow[t]{2}{*}{ Independent Variables } & \multirow[t]{2}{*}{$\mathbf{A Y}$} & \multicolumn{2}{|c|}{ Dependent Variables } \\
\hline & & $\mathbf{A X}$ & AMM \\
\hline \multicolumn{4}{|l|}{$\overline{E g y p t}$} \\
\hline $\mathrm{AY}$ & - & $\begin{array}{c}9.441692 \\
(0.0510)^{* *}\end{array}$ & $\begin{array}{l}6.312555 \\
(0.1770)\end{array}$ \\
\hline $\mathrm{AX}$ & $\begin{array}{c}12.12238 \\
(0.0165)^{* * *}\end{array}$ & - & $\begin{array}{c}2.829385 \\
(0.5868)\end{array}$ \\
\hline AMM & $\begin{array}{l}8.462452 \\
(0.0760)^{*}\end{array}$ & $\begin{array}{c}18.77716 \\
(0.0009)^{* * *}\end{array}$ & - \\
\hline Lagged ECT & {$[-0.660036]^{* *}$} & [19.60309] & {$[16.47573]$} \\
\hline \multicolumn{4}{|l|}{ Morocco } \\
\hline AY & - & $\begin{array}{c}8.711686 \\
(0.0128)^{* * *}\end{array}$ & $\begin{array}{l}1.165515 \\
(0.5584)\end{array}$ \\
\hline $\mathrm{AX}$ & $\begin{array}{c}4.040152 \\
(0.1326)\end{array}$ & - & $\begin{array}{c}25.61590 \\
(0.0000)^{* * *}\end{array}$ \\
\hline AMM & $\begin{array}{l}1.044576 \\
(0.5932)\end{array}$ & $\begin{array}{l}1.254831 \\
(0.5340)\end{array}$ & $(0.000)$ \\
\hline Lagged ECT & {$[-0.980779] * * *$} & {$[1.168880]$} & {$[0.442794]$} \\
\hline \multicolumn{4}{|l|}{ Tunisia } \\
\hline AY & (at & $\begin{array}{c}0.051700 \\
(0.9745)\end{array}$ & $\begin{array}{c}11.81685 \\
(0.0027)^{* * *}\end{array}$ \\
\hline $\mathrm{AX}$ & $\begin{array}{c}11.62245 \\
(0.0030)^{* * *}\end{array}$ & - & $\begin{array}{c}3.132892 \\
(0.2088)\end{array}$ \\
\hline AMM & $\begin{array}{c}9.336255 \\
(0.0094) * * *\end{array}$ & $\begin{array}{l}5.322587 \\
(0.0699)^{*}\end{array}$ & - \\
\hline Lagged ECT & {$[-0.823725] * * *$} & {$[1.356063]$} & {$[0.582888]$} \\
\hline
\end{tabular}

Note. Values in brackets are estimated t-statistics for each cointegration equation. All other values are asymptotic Granger causality F tests (WALD Test), values in parentheses are p-values.

$* * * ; * *$ and $*$ denote significances at $1 \%, 5 \%$ and $10 \%$ levels respectively

Table 5 reports that the coefficient of error correction term (ECT) is significant and has a negative coefficient in the three cases. This means that that imports of agricultural machinery and agricultural exports have a positive effect on agricultural GDP in all countries in the longrun.

In the short run we use WALD test to determine the causal links between the different variables in each country. Table 6 summarizes the results of the WALD test included in Table 5. Table 6 reports that agricultural material imports have a positive effect on economic growth in the short run in the three countries. 
Table 6

Causality links in the short run/ WALD Test

\begin{tabular}{ccc}
\hline Egypt & Morocco & Tunisia \\
\hline $\mathrm{AX}<=>\mathrm{AY}$ & $\mathrm{AY}=>\mathrm{AX}$ & $\mathrm{AX}=>\mathrm{AY}$ \\
$\mathrm{AMM}=>\mathrm{AY}$ & $\mathrm{AX}=>\mathrm{AMM}$ & $\mathrm{AMM}<=>\mathrm{AY}$ \\
$\mathrm{AMM}=>\mathrm{AX}$ & & $\mathrm{AMM}=>\mathrm{AX}$ \\
\hline
\end{tabular}

\section{Conclusion}

In this article, we examined the effect of agricultural material imports on economic growth in the agricultural sector in Tunisia, Morocco and Egypt. In use three time series databases that cover the period 1965 - 2016 and that have been estimated by the Co-integration analysis and the error correction vector model.Empirical results show agricultural exports, imports of materials are co-integrated with economic growth positively in the long run. In all three countries, imports of agricultural materials have a positive influence on economic growth, and in its cointegration link, agricultural exports also have a positive effect on agricultural growth. This is explained by the transfer of technology included in imported agricultural materials that contribute to increase agricultural productivity, reduce production costs, and ensure food security and satisfaction with the level of consumption which leads indirectly, an increase in agricultural exports. All of these effects, whether direct or indirect, emphasize that imports of agricultural materials contribute to agricultural growth in the long run. On the other hand, the labor force in the agricultural sector in the three countries has a level of human capital that allows them to learn the use of imported materials technology and to use it in an efficient and more productive way. Which explains the positive effect of imports of agricultural materials on long-term agricultural growth in the case of Tunisia, Morocco and Egypt, and which also explains the positive effect of agricultural imports on agricultural growth in the case of Tunisia and Egypt.So the countries of North Africa must continue to pursue a growth model that adapts to integrate foreign technology imports and not technological innovation to have agricultural investments characterized by huge productivity and rapid growth in the agricultural sector. 


\section{References}

Acheampong, K. (2013). Crude oil price and economic growth: The case of Ghana. International Journal of Management Research and Technology, 1(3), 140-167.

Ahmed M, Hunjra A.I, Iqbal M.K \& Khalil, J. (2014). Impact of Foreign Direct Investment, Imports, Exports of Goods and Services on Economic Growth of Pakistan. Bulletin of Business and Economics, 3(3), 155-165.

Alavinasab, S. M. (2013). Foreign trade and economic growth in Iran: an empirical study. International Journal of Academic Research in Business and Social Sciences, 3(11), 508-519.

Albiman, M., \& Suleiman, N. N. (2016). The relationship among export, import, capital formation and economic growth in Malaysia. Journal of Global Economics, 4(2), 2375-4389..

Amsden, A. H. (1992). Asia's next giant: South Korea and late industrialization. Oxford University Press on Demand.

Anderson, M. (1989). International Technology Transfer in Agriculture. US Department of Agriculture, Economic Research Service.

Bakari, S. (2017). The Three-Way Linkages Between Export, Import and Economic Growth: New Evidence from Tunisia. Journal of Smart Economic Growth, 2(3), 13-53.

Bakari, S. (2018). The Impact of Citrus Exports on Economic Growth: Empirical Analysis from Tunisia. International Journal of Food and Agricultural Economics (IJFAEC), 6(1), 95112.

Bakari, S., \& Mabrouki, M. (2017). Impact of exports and imports on economic growth: new evidence from Panama. Journal of Smart Economic Growth, 2(1), 67-79.

Bakari, S., \& Mabrouki, M. (2018). The Impact of Agricultural Trade on Economic Growth in North Africa: Econometric Analysis by Static Gravity Model. MPRA Paper 85116, University Library of Munich, Germany.

Bakari, S., Mabrouki, M., \& Othmani, A. (2018). The Six Linkages Between Foreign Direct Investment, Domestic Investment, Exports, Imports, Labor Force And Economic Growth: New Empirical And Policy Analysis From Nigeria. Journal of Smart Economic Growth, 3(1), 25-43.

Barro, R.J. \& Sala-i-Martin, X., (1997). Technological diffusion, convergence, and growth. Journal of Economic Growth 2, 1-26.

Benhabib, J., \& Spiegel, M. M. (2002). Human Capital and Technology Diffusion. FRB of San Francisco Working Paper, (2003-02). 
Cameron, G., Proudman, J., \& Redding, S. (2005). Technological convergence, R\&D, trade and productivity growth. European Economic Review, 49(3), 775-807.

Chenery, H. B., \& Bruno, M. (1962). Development alternatives in an open economy: the case of Israel. The Economic Journal, 72(285), 79-103.

De Janvry, A., \& Sadoulet, E. (2002). World poverty and the role of agricultural technology: direct and indirect effects. Journal of development studies, 38(4), 1-26.

Dickey, D. A., \& Fuller, W. A. (1979). Distribution of the estimators for autoregressive time series with a unit root. Journal of the American statistical association, 74(366a), 427-431.

Dickey, D. A., \& Fuller, W. A. (1981). Likelihood ratio statistics for autoregressive time series with a unit root. Econometrica: journal of the Econometric Society, 1057-1072.

Ghosh, S. (2009). Import demand of crude oil and economic growth: Evidence from India. Energy Policy, 37(2), 699-702.

Griffith, R., Redding, S., \& Reenen, J. V. (2004). Mapping the two faces of R\&D: Productivity growth in a panel of OECD industries. Review of economics and statistics, 86(4), 883-895.

Grossman, G. M., \& Helpman, E. (1991). Innovation and growth in the global economy. MIT press.

Hassine, N. B. (2008). Trade, human capital, and technology diffusion in the Mediterranean agricultural sector. Economie internationale, (1), 115-142.

Hussain, M. A. (2014). Economic growth, exports and imports in Pakistan: Granger causality analysis. The Journal of Business in Developing Nations, 13, 31-62.

Hye, Q.M.A (2012). Exports, imports and economic growth in China: an ARDL analysis. Journal of Chinese Economic and Foreign Trade Studies, 5(1), 42-55.

Jayaraman, T. K., \& Lau, E. (2011). Oil price and economic growth in small Pacific Island countries. Modern Economy, 2(2), 152-161.

Johansen, S. (1988). Statistical analysis of cointegration vectors. Journal of economic dynamics and control, 12(2-3), 231-254.

Johansen, S. (1991). Estimation and hypothesis testing of cointegration vectors in Gaussian vector autoregressive models. Econometrica: Journal of the Econometric Society, 1551-1580.

Johansen, S., \& Juselius, K. (1990). Maximum likelihood estimation and inference on cointegration - with applications to the demand for money. Oxford Bulletin of Economics and statistics, 52(2), 169-210.

McKinnon, R. I. (1964). Foreign exchange constraints in economic development and efficient aid allocation. The Economic Journal, 74(294), 388-409.

Mohsen, A. S. (2015). Effects of exports and imports on the economic growth of Syria. Euro-Asian Journal of Economics and Finance, 3(4), 253-261. 
Ofeh, M. A., \& Muandzevara, A. T. (2017). Investigating the Effects of Migrant Remittances on the Economic Growth of Cameroon. International Journal of Economics and Finance, 9(2), 58-69.

Riyath, M.I.M \& Jahfer, A. (2016). Exports, Imports and Economic Growth in Sri Lanka: Evidence from Causality and Co-Integration Analysis. 5th Annual International Research Conference- 2016. Faculty of Management and Commerce- SEUSL.

Sims, C. A. (1980). Macroeconomics and reality. Econometrica: journal of the Econometric Society, 1-48.

Taylor, L. (1991). Income Distribution, Inflation, and Growth. Cambridge, MA: MIT Press.

Turan, G., \& Karamanaj, B. (2014). An empirical study on import, export and economic growth in Albania. Academic Journal of Interdisciplinary Studies, 3(3), 428-438.

Yazdani, M. \& Faaltofighi, M. (2012). Study the causal relationship between economic growth and energy consumption in energy (oil) exporting and importing counrties. Australian Journal of Basic and Applied Sciences, 74(4), 500-504.

Yüksel, S., \& Zengin, S. (2016). Causality Relationship Between Import, Export and Growth Rate in Developing Countries. International Journal of Commerce and Finance, 2(1), 147-156.

Zhang, X., \& Zou, H. F. (1995). Foreign technology imports and economic growth in developing countries (No. 1412). The World Bank. 